\title{
NASAL AESTHETIC EVALUATION FOLLOWING PRE-SURGICAL NASO-ALVEOLAR MOLDING APPLICATION: A SINGLE-BLINDED COHORT RETROSPECTIVE STUDY IN INDONESIA
}

Kristaninta Bangun ${ }^{1 *}$, Chaula Luthfia Sukasah ${ }^{1}$, Jenisa Amanda Sandiarini Kamayana ${ }^{2}$, Adi Basuki ${ }^{1}$, Jessica Halim ${ }^{1}$, Nur Eulis Pujiastuti Nahdiyat ${ }^{2}$, Agatha Novell Harsanto ${ }^{3}$, \& Arvin Pramudita ${ }^{2}$. 1. Division of Plastic Surgery, Department of Surgery, Faculty of Medicine Universitas Indonesia, Cipto Mangunkusumo General Hospital, Jakarta, Indonesia.

2. Faculty of Medicine, Universitas Indonesia, Jakarta, Indonesia.

3. Faculty of Medicine, Diponegoro University, Jalan Prof Sudharto, Tembalang, Semarang, Central Java, Indonesia.

\begin{abstract}
Introduction: As a major facial aesthetic unit, the nose is one of the significant features in cleft lip and palate repair. The use of naso-alveolar molding (NAM) device was known to help narrow the cleft gap and improve nasal aesthetics. This study aims to evaluate post-operative nasal morphology in unilateral cleft lip and palate patients who had used presurgical NAM, particularly in an established craniofacial centre in one of developing countries. Methods: A cohort retrospective study was conducted at Cleft Craniofacial Centre, Cipto Mangunkusumo Hospital Indonesia, comparing the nasal symmetry in unilateral cleft lip patients with and without prior application of NAM (NAM and control group), twelve months following primary cheiloplasty. Differences between the cleft and normal side were assessed using standard basilar view photographs based on five points nasal measurements.

Results: A total of twelve patients were enrolled, six with a history of NAM application and six without (control). Overall nasal measurements confirmed lower mean of differences in the NAM group compared to the control, showing statistically significant results in nostril height, nasal dome height, and columellar height $(\mathrm{p}<0.05)$.

Conclusion: This study provides an insight that cleft lip patients with history of NAM application had superior nasal symmetry compared to patients without presurgical NAM application 1-year post-cheiloplasty. Presurgical NAM application is recommended for patients with unilateral cleft lip and palate.

Keywords: Nasoalveolar Molding; Nasal Aesthetic; Labioplasty; Cleft Lip; Cleft Palate
\end{abstract}

ABSTRAK
Introduksi: Sebagai bagian estetika wajah, hidung merupakan salah satu bagian penting dalam perbaikan bibir
sumbing dan langit-langit. Penggunaan alat naso-alveolar molding (NAM) diketahui dapat membantu
mempersempit celah sumbing dan meningkatkan estetika hidung. Penelitian ini bertujuan untuk mengevaluasi
morfologi hidung pasca operasi pada pasien sumbing bibir dan langit-langit unilateral yang telah menggunakan
NAM sebelum pembedahan, khususnya di pusat kraniofasial yang sudah memadai di salah satu negara
berkembang.
Metode: Penelitian kohort retrospektif dilakukan di Cleft Craniofacial Centre, RS Cipto Mangunkusumo Indonesia,
membandingkan simetri hidung pada pasien bibir sumbing unilateral dengan dan tanpa aplikasi NAM (NAM dan
kelompok kontrol), dua belas bulan setelah cheiloplasty primer. Perbedaan antara sumbing dan sisi normal dinilai
menggunakan foto tampilan basilar standar berdasarkan lima titik pengukuran hidung.
Hasil: Sebanyak dua belas pasien terdaftar, enam dengan riwayat aplikasi NAM dan enam tanpa NAM (kontrol).
Pengukuran hidung secara keseluruhan mengkonfirmasi perbedaan rata-rata yang lebih rendah pada kelompok
NAM dibandingkan dengan kontrol, menunjukkan hasil yang signifikan secara statistik pada tinggi lubang
hidung, tinggi kubah hidung, dan tinggi kolumelar (p <0,05).
Kesimpulan: Penelitian ini memberikan gambaran bahwa pasien bibir sumbing dengan riwayat aplikasi NAM
memiliki kesimetrisan hidung yang lebih baik dibandingkan dengan pasien tanpa aplikasi NAM, 1 tahun pasca
cheiloplasty. Aplikasi NAM direkomendasikan untuk pasien dengan sumbing bibir dan langit-langit unilateral.
Kata kunci: Nasoalveolar Molding; Estetika Hidung; Labioplasti; Bibir Sumbing; Sumbing Langit-langit

Conflicts of Interest Statement:

The author(s) listed in this manuscript declare the absence of any conflict of interest on the subject matter or materials discussed. 
Presented at the The $16^{\text {th }}$ International Congress of Oriental Society of Aesthetic Plastic Surgery in conjunction with International Society of Plastic Surgery Symposium and $10^{\text {th }}$ National Congress and $22^{\text {th }}$ Annual Scientific Meeting of Indonesian Association of Plastic Surgery.

\section{INTRODUCTION}

The orofacial cleft is the most common congenital facial and oral malformations worldwide; which includes cleft lip, cleft palate, or combination of both. ${ }^{1}$ According to the statistics, the prevalence of oral cleft is $1-2$ in 1000 live births worldwide. ${ }^{2}$ Variations in prevalence are seen between different sex and ethnicity. 3,4 Studies found that Asians generally possess a higher risk of having orofacial cleft than Caucasians and African Americans, scoring 2.1 for every 1000 live births. 5,6

Most studies described a higher incidence of cleft lip and palate in male patients. ${ }^{7,8}$ On the other hand, current epidemiology study on cleft deformities in Indonesia is still lacking, therefore an update on national epidemiological data is needed. Lubis et al. reported cleft lip and palate as one of the four most common congenital malformations in a hospital in Medan, Indonesia between the year 1981-1984, constituting 7.7\% of the total cases. ${ }^{9}$ Whilst a separate study in a hospital in Manado, Sulawesi throughout 19831987 showed that cleft lip and palate malformations accounted up to $10.2 \%$ of all malformation cases, the highest amongst other malformations recorded. ${ }^{10}$

The morphological structure of the nose greatly influences the overall aesthetics of the face. The nose is one of the major facial aesthetic units. One of the main goals of cleft lip and palate repair is to achieve nasal symmetry. Furthermore, the burden of orofacial clefts is beyond mere facial aesthetics; unrepaired clefts greatly affects speech and are associated with feeding problems, otitis media, and hearing loss.11,12 In unilateral cleft lip, the lower lateral nasal cartilage is depressed and the septal cartilage is displaced, altogether resulting in an asymmetrical tip, asymmetrical length of the alar rim, drooping of the alar height, and shortened columella in the affected side.13,14 Therefore, reconstruction of unilateral cleft lip remains a challenge.

The journey to excellent surgical outcome starts with targeted preoperative management. Grayson et al. first introduced the use of nasoalveolar molds in infants with cleft lip and palate. 15 The nasoalveolar molding (NAM) device incorporates an oral molding plate with attached nasal stents personalized for every patient's specific features (Figure 1). This manipulation should be initiated as early as possible, considering that the high level of estrogen in newborns was believed to correlate with upregulation of hyaluronic acid production, which inhibits the linking of the cartilage in the intercellular matrix. Moreover, the level of estrogen begins to decline immediately after birth. ${ }^{14}$

The NAM is expected to aid the repair of columella, nasal cartilage and alveolar deformity by utilizing infants' cartilage malleability and accommodating for maxillary alveolar approximation. ${ }^{15}$ The reduction of cleft width prior to primary closure also minimizes scar formation following repair, contributing to more appealing result. ${ }^{15}$ Additionally, the pre-surgical procedure preceding primary cleft repair was reported to abolish the need of secondary reconstructive surgery. ${ }^{16,17}$ A technique by Liou et al. demonstrated an improvement of nasal symmetry with the use of pre-surgical nasoalveolar molding, despite the presence of relapses. ${ }^{18}$

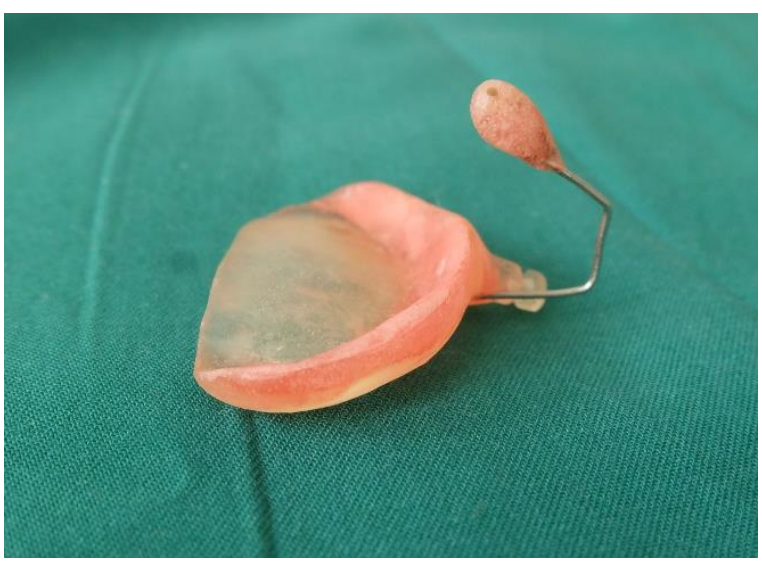

Figure 1. The Naso-Alveolar Molding (NAM) device (used in our center). The Liou Technique was used to create this device. Note the oral molding plate with attached nasal stents, which was specifically designed for each individual. NAM device should be used before the primary lip repair takes place.

In Indonesia, additional expenses spent on NAM is not included in the national healthcare coverage, thus patients who agree on using NAM device would need to provide for 
their own. The added cost greatly influence the family's decision on using NAM. Moreover, the literature about NAM experience in South East Asia is still scant. In this study, researchers aim to evaluate nasal morphology post-operatively in unilateral cleft lip patients who had used presurgical NAM at an established craniofacial centre in Indonesia. Study was conducted by analysing differences in measurements of the nasal anatomy. We expected that the study could confirm the benefit of pre-surgical NAM application in patients with unilateral clefts.

\section{METHOD}

A cohort retrospective study was conducted at Cleft Craniofacial Centre (CCC) Cipto Mangunkusumo Hospital to compare the nasal measurements post-cheilopalatoplasty between those with and without the history of pre-surgical NAM application. Data was acquired from medical records, selecting relevant patients between 2013 and 2016. The calculated sample size was 20 with a power of $80 \%$. Informed consent of their participation in the study had been obtained from the parents. Ethical approval number 0440/UN2.F1/ETIK/2018 had been granted by The Ethics Committee of the Faculty of Medicine, University of Indonesia.

Inclusion criteria for the NAM (treatment) group include: (1) complete unilateral cleft lip and palate; (2) a minimum of 3 months NAM application with good compliance, which is defined as continuous usage with removal only for bathing; and (3) had not been diagnosed with other craniofacial malformations or systemic diseases. Patients were excluded if cheiloplasty was performed less than 12 months before the measurement and if the surgery was not conducted at Cipto Mangunkusumo Hospital.

\section{Measurement}

The baseline characteristics, operation data, and NAM usage compliance were collected from the medical records. All eligible patients were examined at the follow-up meeting for primary data collection, including history taking, physical examination, and basilar view photograph of the nose.

The standard basilar view photographs to measure nasal symmetry were taken according to commonly used technique from similar previous study. ${ }^{18}$ The patient's head was tilted back to bring the alar dome above the canthi yet below the eyebrows. The photographs were captured with a paper ruler as a benchmark. Three photographs were taken for each patient and one was picked subjectively. The selected photograph was measured three times at different timepoints using ImageJ®. The five linear measurements were taken and measured directly on the photographs.

The photographs and measurements taken were as follows (Figure 2 and 3):

- Nostril height (a): the distance measured from horizontal reference line perpendicular to the intersection of supero-medial of the nostril and nostril width bisecting line

- Nasal dome height (b): the distance measured from the horizontal reference line perpendicular to intersection of the outer border of the nasal dome and nostril width bisecting line

- Columella length (c): the distance measured from the most superior medial to the most inferior-medial of the medial side of nostril apertures. If the measurement line is extended, $90^{\circ}$ angle should be formed with the horizontal reference.

- Nostril width (d): the distance measured from the most inner medial border of nostril apertures to the most outer lateral border of the nostril. The line should be parallel with the horizontal reference line.

- Nostril basal width (e): the distance measured from the most inner medial to the most inner lateral of the nostril apertures. The line should be parallel with the horizontal reference line.

\section{Outcomes}

The primary outcome was the nasal symmetry between the left and right side, measured by identifying the differences in several nasal measurement variables. Differences were calculated by subtracting measurements of the normal nasal side with the cleft side, in millimetres. All variables of the outcome were presented in modulus and reviewed by one of the authors who was unaware of the study-group assignment.

$$
\begin{gathered}
\text { Difference }=\left|a_{1}-a_{2}\right| \\
\mathrm{a}_{1}=\text { Non-cleft side } \\
\mathrm{a}_{2}=\text { Cleft side }
\end{gathered}
$$




\section{Statistical Analysis}

Variables were reported as means \pm standard deviation. Differences between continuous variables were analysed using the two-tailed nonpaired $t$-test and/or Mann-Whitney test depending on the normality test result. Whereas differences between distributions were assessed using the Pearson's $x 2$ test. Statistical significance was inferred with a value of $p$ less than 0.05 .

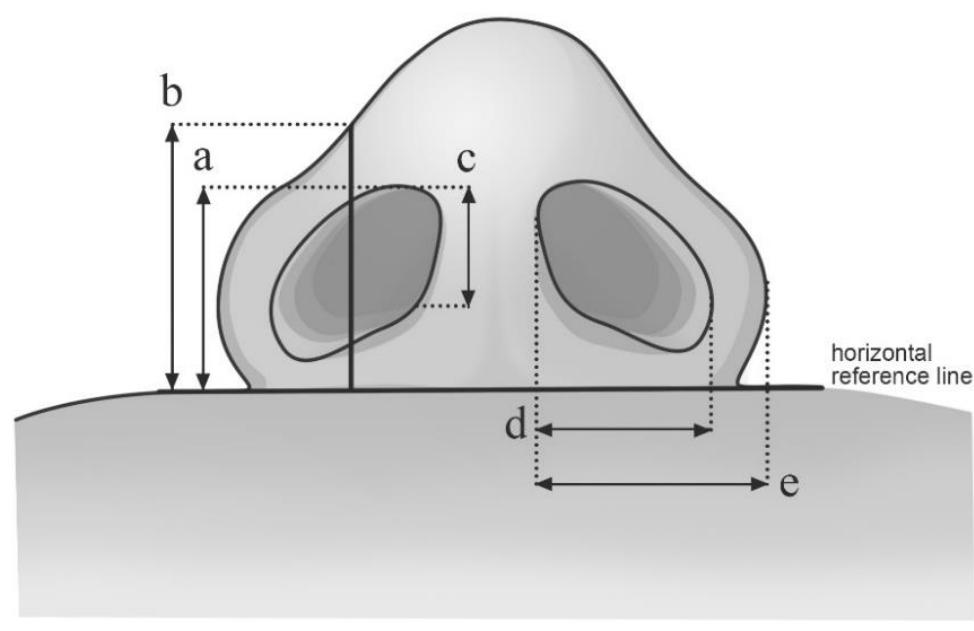

Figure 2. Five nasal measurement consisting of measurements of nostril height (a), nasal dome height (b), columella length (c), nostril width (d), nostril basal width (e).

A

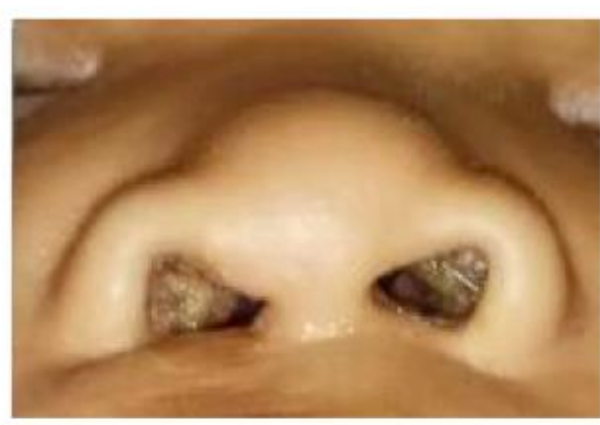

B

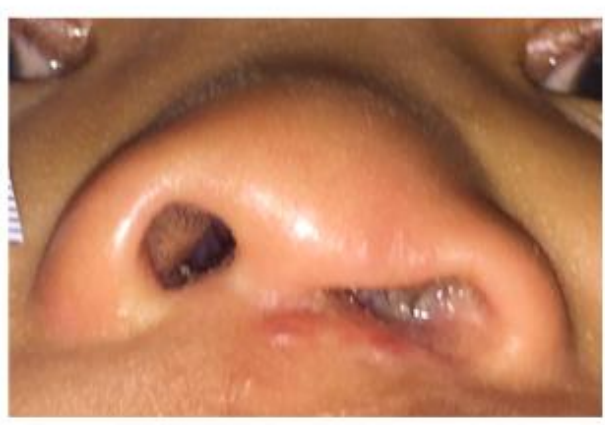

Figure 3. Basilar view of (A) patient with history of pre-surgical NAM application and (B) patient without history of pre-surgical NAM application, observed 1 year following primary cheiloplasty.

\section{RESULTS}

A total of twelve consecutive patients (6 males, 6 females) were included in this study and assigned into 2 treatment groups: 6 patients with the history of pre-surgical NAM application (NAM group) and 6 without (control group) (Table 1). The number of individuals at each stage of the selection process was displayed below (Figure 4 and 5). There were 9 left-sided and 3 right-sided clefts. Modified Millard method for cleft lip repair was mostly used by the majority of the surgeons in this study. In all five nasal measurement variables, the NAM group showed a lower mean of difference compared to the control group (Table 2.) Furthermore, the nostril height (a), nasal dome height (b), and the columella length (c) statistically showed significant symmetry between both normal and cleft side in the NAM group ( $p=0.007, p=0.001$, and $p=0.021$ respectively). 


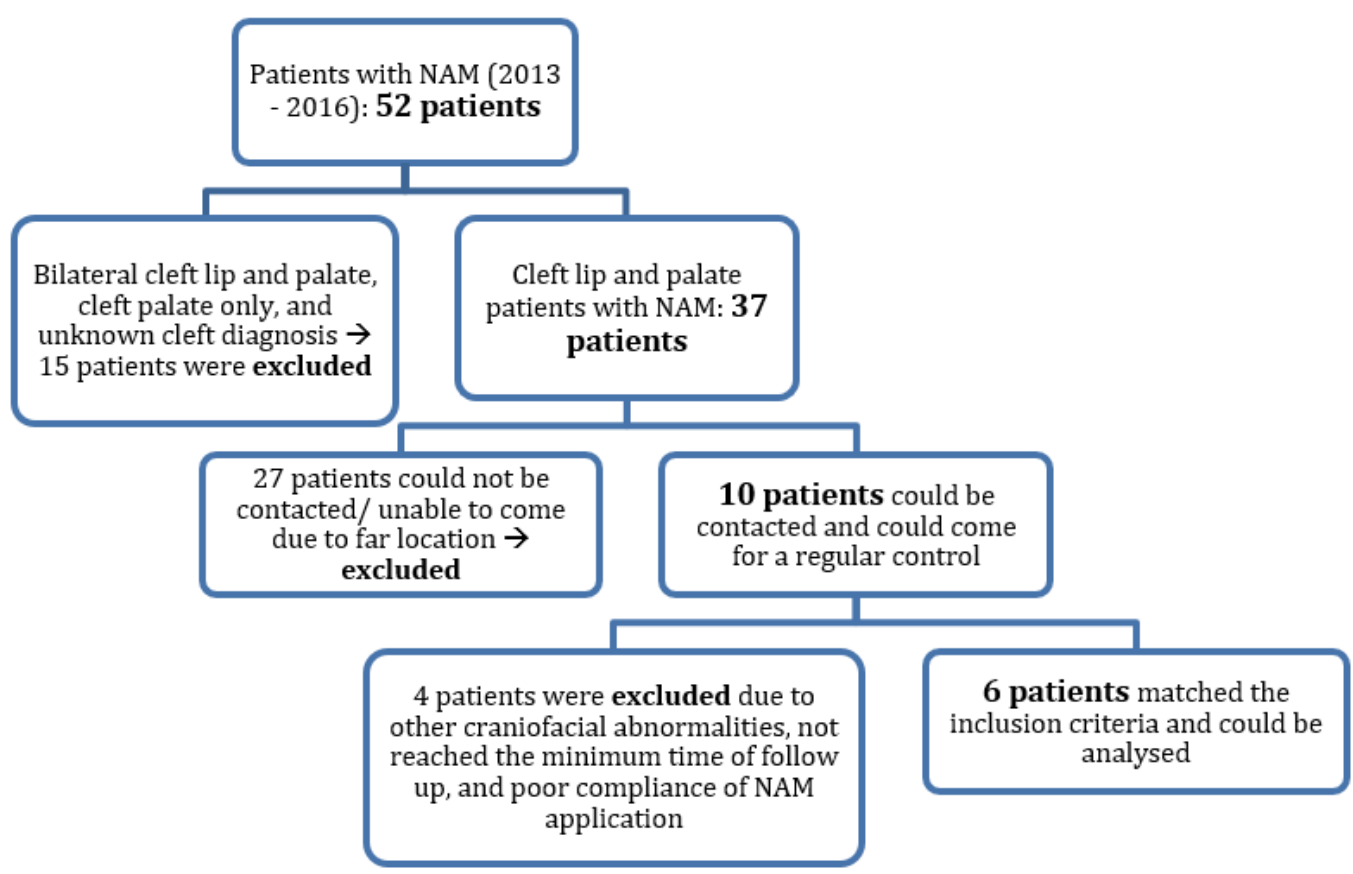

Figure 4. Flow diagram of the NAM group.

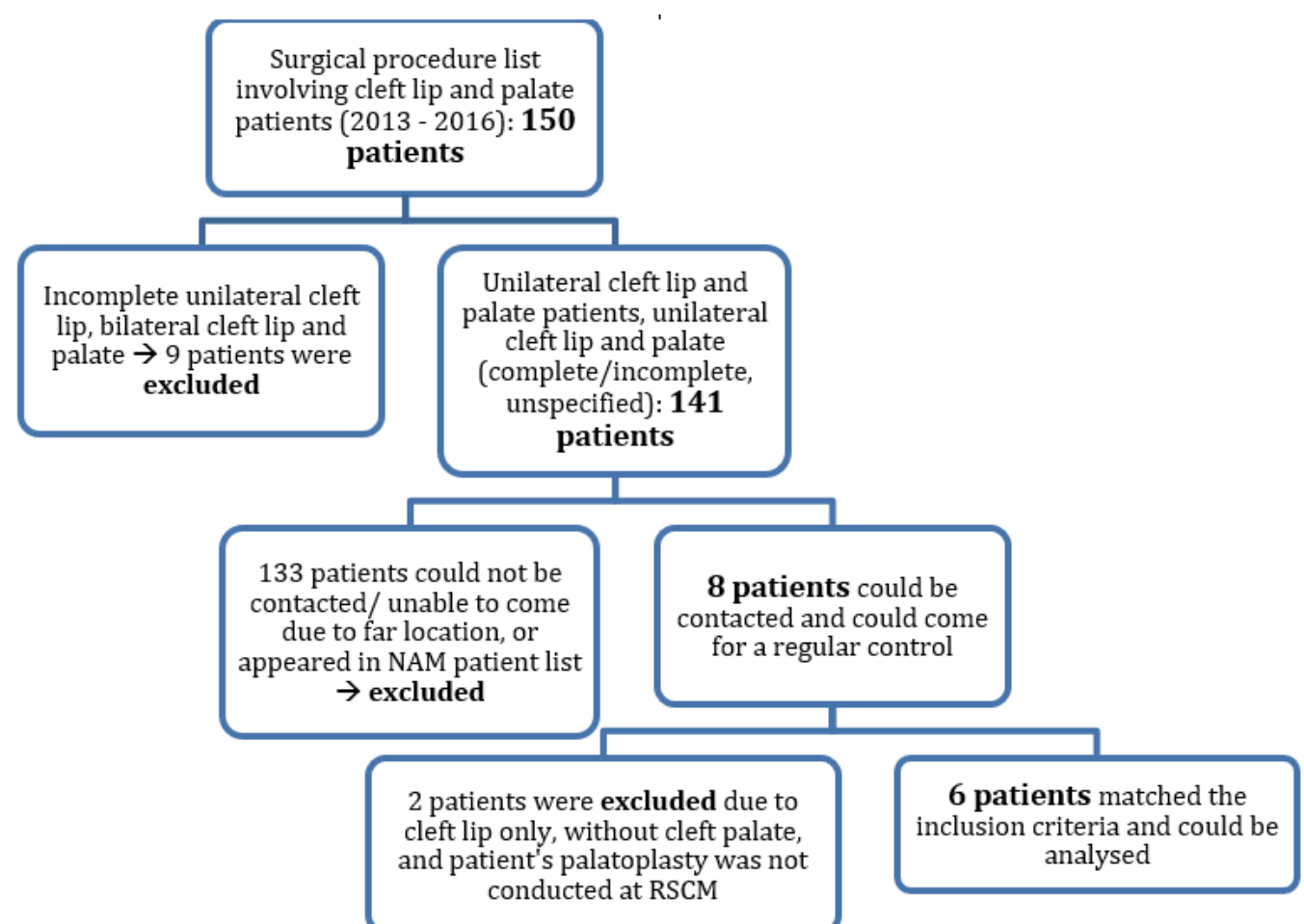

Figure 5. Flow diagram of the control group. 
Table 1. Baseline characteristics between groups

\begin{tabular}{|c|c|c|}
\hline & NAM $(n=6)$ & Control $(n=6)$ \\
\hline Age* & $35.5(26-36)$ months & $33.5(21-45)$ months \\
\hline Male & 2 patients & 4 patients \\
\hline Female & 4 patients & 2 patients \\
\hline Left-side cleft & 4 patients & 5 patients \\
\hline Right-side cleft & 2 patients & 1 patient \\
\hline First initiation of NAM* & 21 (13-44) days & - \\
\hline $\begin{array}{l}\text { The age at labioplasty } \\
\text { Mean } \pm \text { SD }(95 \% \mathrm{CI})^{* *}\end{array}$ & $4.83 \pm 1.33$ (3.44-6.23) months & $3.67 \pm 0.82(2.81-4.52)$ months \\
\hline $\begin{array}{l}\text { Duration of NAM use } \\
\text { Mean } \pm \text { SD }(95 \% \mathrm{CI})^{\star *}\end{array}$ & $4.5 \pm 1.05$ (3.40-5.60) months & - \\
\hline $\begin{array}{l}\text { The age at palatoplasty } \\
\text { Mean } \pm \text { SD }(95 \% \mathrm{CI})^{* *}\end{array}$ & $14.67 \pm 3.08$ (11.44-17.90) months & $\begin{array}{l}14.83 \pm 4.40(10.22-19.45) \\
\text { months }\end{array}$ \\
\hline \multicolumn{3}{|l|}{ Technique of operation } \\
\hline 1. Modified Millard & 4 & 6 \\
\hline 2. Fisher & 2 & 0 \\
\hline
\end{tabular}

Table 2. Nasal symmetry between groups

\begin{tabular}{|c|c|c|c|}
\hline Variables & Mean $\pm S D^{*}$ & $\mathrm{P}^{* *}$ & $95 \% \mathrm{CI}$ \\
\hline \multicolumn{4}{|l|}{$\mathrm{A}$} \\
\hline No history of NAM & $3.40 \pm 1.13$ & 0.007 & $1.92(0.67-3.17)$ \\
\hline With history of NAM & $1.48 \pm 0.71$ & & \\
\hline \multicolumn{4}{|l|}{ B } \\
\hline No history of NAM & $2.93 \pm 0.72$ & 0.001 & $1.73(0.90-2.57)$ \\
\hline With history of NAM & $1.20 \pm 0.54$ & & \\
\hline \multicolumn{4}{|l|}{$\mathrm{C}$} \\
\hline No history of NAM & $1.54 \pm 0.61$ & 0.021 & $0.89(0.17-1.59)$ \\
\hline With history of NAM & $0.66 \pm 0.49$ & & \\
\hline \multicolumn{4}{|l|}{$\mathrm{D}$} \\
\hline No history of NAM & $2.19 \pm 2.04$ & 0.525 & $0.63(-1.57-2.82)$ \\
\hline With history of NAM & $1.57 \pm 1.09$ & & \\
\hline \multicolumn{4}{|l|}{$\mathrm{E}$} \\
\hline No history of NAM & $2.07 \pm 1.80$ & 0.768 & $0.27(-1.75-2.30)$ \\
\hline With history of NAM & $1.79 \pm 1.25$ & & \\
\hline
\end{tabular}




\section{DISCUSSION}

This study took place in a cleft craniofacial centre in a developing country, in which a multi-disciplinary approach, is established and implemented in the patient management. The multi-disciplinary team consists of plastic surgeons, orthodontists, paediatricians, and physical rehabilitation physicians.

Five-point nasal measurements used in this study showed a clinically significant lower mean of differences in the NAM group compared to the control group. This finding suggested the superiority of pre-surgical NAM application to improve nasal symmetry and overall aesthetic results. Moreover, the nasal dome height showed consistent and significant results, both clinically and statistically, as confirmed by other studies on short-term and long-term follow-up. 19.20,21,22

A study by Rachwalski and colleagues in India, which assessed the nasal symmetry prior to primary cheiloplasty using basal view photographs, found that the pre-surgical NAM application exhibited superior nasal aesthetics at the age of 6-7 months by elevating nasal height $(P=0.003)$, enhancing nasal width $(P=0.007)$, improving columellar length $(P=0.02)$, and correcting columellar angle $(P=0.02) .{ }^{19}$ Several studies also presented positive results on nasal symmetry on short-term follow-ups. ${ }^{20,21,22}$ However, those studies did not involve any control group as direct comparison.

The application of pre-surgical NAM possesses several objectives related to improved nasal aesthetics, for instance: to repair the mispositioned nasal cartilages, to elongate columella and philtrum; to give a natural curve to the alar rim, to fetch the columella towards the midsagittal plane, and to enhance nasal symmetry. ${ }^{14}$ It allows stimulation and redirection of growth for the repositioning of the alveolar segments as well as shapes the ideal arch form, normalizes the tongue position, aids in speech development, improves appearance, provides psychosocial assurance, and improves feeding and bone contour. ${ }^{23}$ Even though NAM was believed to provide a promising nasal aesthetic result on short-term follow-up, study in a longterm period remains unknown. 9 year-follow-up following the surgery demonstrated more consistent results from 2 out of 3 basilar view measurements. Nasal dome height and nasal ala projection length showed statistically significant difference, yet columellar deviation was shown to be reciprocal. ${ }^{24}$ Another study by Bennum and colleagues also showed significant improvements in nasal tip protrusion and columellar length on 6 year follow up, as similarly proven in this study. ${ }^{25}$ These results justify our findings, suggesting that pre-surgical NAM application significantly improved nasal aesthetic especially the columella length and the nasal dome height.

However, several limitations were found in this study. The small number of enrolled participants was the major limiting factor due to loss to contact and loss to follow up. The centre accepts referred patients nationwide and therefore majority of the patients live far from the capital, which potentially hindered the follow-up process. The outcomes were also limited to a twodimensional photographic measurements and first initiation of NAM application that were often not started at the ideal age (one-monthold). ${ }^{26}$ The unpunctual timing of hospital admission was speculated to delay the patient from receiving immediate treatment. Timing of the surgery also varied among patients. Additionally, surgeries were performed by different plastic surgeons with non-uniformed techniques and non-levelled skills, which might subjectively impact the results. Lastly, there was a lack of supervision to assess patient's compliance throughout the NAM application period. Further randomized controlled trial on a larger scale performed by the same operator with consistent techniques asssesed on long-term follow-up is required to provide high-level evidence on pre-surgical NAM application prior to primary cheiloplasty.

\section{CONCLUSION}

This study demonstrated a valuable insight that patients receiving pre-surgical NAM achieved better nose symmetry than patients who had no history of NAM on 1 year follow up postcheiloplasty at an established craniofacial centre in developing country. Significant differences were observed in nostril height, nasal dome height and columella length measurements. Despite the limitations of the study, the use of pre-surgical NAM should be considered for all patients with unilateral cleft lip and palate, regardless of the patient's economic status. 


\section{ACKNOWLEDGEMENTS}

We would like to thank all the staff at Cleft Craniofacial Centre, Cipto Mangunkusumo Hospital for their surgical and orthodontic expertise and for showing support towards this study. We would also like to thank drg. Julieta Pancawati, SpOrt, dr. Marini Mihardjanti, SpOrt, and dr. Muhammad Iqbal Maulana for their help in carrying out this study and dr. Indra Wicaksono, who kindly provided the measurement illustration.

\section{Correspondence regarding this article should be addressed to: \\ Kristaninta Bangun, MD, Ph.D. Head of Cleft and Craniofacial Centre; Division of Plastic, Reconstructive, and Aesthetic Surgery; Department of Surgery; Universitas Indonesia; Cipto Mangunkusumo General Hospital, 71 Diponegoro Street, Jakarta, Indonesia \\ +62-81398613820 \\ E-Mail: kristaninta.s3@gmail.com}

\section{REFERENCES}

1. Shaye D, Liu CC, Tollefson TT. Cleft Lip and Palate: An Evidence-Based Review. Facial Plast Surg Clin North Am. 2015 Aug. 23 (3):357-72.

2. Watkins, S. E., Meyer, R. E., Strauss, R. P., \& Aylsworth, A. S. (2014). Classification, Epidemiology, and Genetics of Orofacial Clefts. Clinics in Plastic Surgery, 41(2), 149 163.doi:10.1016/j.cps.2013.12.003

3. Calzolari E, Bianchi F, Rubini $\mathrm{M}$, et al. ; EUROCAT Working Group. Epidemiology of cleft palate in Europe: implications for genetic research. Cleft Palate Craniofac J. 2004;41:244-249

4. Butali A, Mossey PA. Epidemiology of orofacial clefts in Africa: methodological challenges in ascertainment. Pan Afr Med J. 2009;2:5.

5. Jafari A, Zarea K, Mehregan N. The Prevalence of Cleft Lip and Cleft Palate and Related Risk Factors among Iranian Children from 2000 to 2016: a Literature Review. Int J Pediatr 2017; 5(4): 4687-97.
6. Widayanti N, Sudjatmiko G, Putri NM. Parental Age as a Risk Factor of Children with Cleft Lip in Jakarta Population: Does Paternal Age Play a Role?. Jurnal Plastik Rekonstruksi. 2017; 1:88-94

7. Cooper ME, Stone RA, Liu YE. Hu DN, Melnick M, Marazita ML. Descriptive epidemiology of nonsyndromic cleft lip with or without cleft palate in Shanghai, Cina, from 1980 to 1989. Cleft Palate Craniofac J. 2000;37(3):274-80.

8. Jagomagi T, Soots M, Saag M. Epidemiologic factors causing cleft lip and palate and their regularities of occurrences in Estonia. Baltic Dental and Maxillofacial Journal. 2010;12:105-8.

9. Lubis B, Tjipta GD, Panjaitan AJ, Raid N, Siregar H. Congenital Malformation Among Newborns at Dr. Pirngadi Hospital Medan During 1981-1984. Paediatrica Indonesiana. 1989;29:1-7.

10. Masloman N, Mustadjab I, Munir M. Congenital Malformation at Guning Wenang Hospital Manado: A Five-Year Spectrum. Paediatrica Indonesiana. 1991;31:294-302.

11. Gkantidis N, Papamanou DA, Karamolegkou M, Dorotheou D. Esthetic, Functional, and Everyday Life Assessment of Individuals with Cleft Lip and/or Palate. BioMed research international. 2015 Apr 5;2015

12. Gani B, Kinshuck AJ, Sharma R. A Review of Hearing Loss in Cleft Palate Patients. Int $J$ Otolaryngol. 2012;2012:548698.

13. McComb HK, Coghlan BA. Primary Repair of the Unilateral Cleft Lip Nose: Completion of a Longitudinal Study. Cleft Palate Craniofac J. 1996:33(1):23-30.

14. Grayson BH, Maull D. Nasoalveolar Molding for Infants Born with Clefts of the Lip, Alveolus, and Palate. Semin Plast Surg. 2005;19(4):294-301

15. Grayson BH, Santiago PE, Brecht LE, Cutting CB. Presurgical Nasoalveolar Molding in Infants with Cleft Lip and Palate. Cleft PalateCraniofac J. 1999;36(6):486-498

16. Santiago PE, Grayson BH, Gianoutsos MP, Kwon SM, Brecht LE, Cutting CB. Reduced Need for Alveolar Bone Grafting by Presurgical Orthopedics and Primary Gingivoperiosteoplasty. Cleft Palate Craniofac J. 1998;35:77-80.

17. Henkel K, Gundlach K. Millard gingivoperiosteoplasty: an alternative to 
osteoplasty of alveolar clefts. Mund Kiefer Gesichtschir 2002;6:261-265

18. Liou EJW, Subramanian M, Chen PKT, and Huang CS. The Progressive Changes of Nasal Symmetry and Growth after Nasoalveolar Molding: A Three-Year Follow-Up Study. Plast Reconstr Surg. 2004;114: 858-64.

19. Rachwalski M, Pullan S, Parmar R, Shetty PN, Sharma P, Bonanthaya K. Nasal aesthetics in unilateral cleft lip and palate with and without presurgical nasoalveolar molding: a preliminary assessment. International Journal of Oral and Maxillofacial Surgery. 2017 Mar 1;46:68.

20. Gomez DF, Donohue ST, Figueroa AA, Polley JW. Nasal changes after presurgical nasoalveolar molding (PNAM) in the unilateral cleft lip nose. The Cleft PalateCraniofacial Journal. 2012 Nov;49(6):689-700

21. Keçik D, Enacar A. Effects of nasoalveolar molding therapy on nasal and alveolar morphology in unilateral cleft lip and palate. Journal of Craniofacial Surgery. 2009 Nov 1;20(6):2075-80

22. Jaeger M, Braga-Silva J, Gehlen D, Sato $Y$, Zuker R, Fisher D. Correction of the alveolar gap and nostril deformity by presurgical passive orthodontia in the unilateral cleft lip. Annals of plastic surgery. 2007 Nov 1;59(5):489-94

23. Patel D, Goyal R, Puri T. Presurgical nasoalveolar moulding - An adjunct to facilitate surgical repair in infants with cleft lip and palate. Mod Plast Surg. 2013;3:34-42.

24. Barillas I, Dec W, Warren SM, Grayson BH. Nasoalveolar molding improves long-term nasal symmetry in complete unilateral cleft lip-cleft palate patients. Plastic and reconstructive surgery. 2009 Mar 1;123(3):1002-6.

25. Bennun RD, Perandones C, Sepliarsky VA, Chantiri SN, Aguirre MI, Dogliotti PL. Nonsurgical correction of nasal deformity in unilateral complete cleft lip: a 6-year followup. Plastic and reconstructive surgery. 1999 Sep;104(3):616-30

26. Shetty V, Vyas HJ, Sharma SM, Sailer HF. A Comparison of results using nasoalveolar molding in cleft infants treated within 1 month of life versus those treated after this period: development of new protocol. Int J Oral Maxillofac Surg.; 2012;41(1):28-36 